\title{
MENCEGAH LEBIH EFEKTIF DARI PADA MENANGANI (KASUS BULLYING PADA ANAK USIA DINI)
}

\author{
Sitti Rahmaniar Abubakar \\ Jurusan PG-PAUD, Universitas Halu Oleo.Jln. H.E.A Mokodompit, Kendari 93232, Indonesia. \\ E-mail: sitirahmaniar@ymail.com, Telp: 085299580506
}

\begin{abstract}
Abstrak
Fenomena tindak kekerasan yang terjadi di seluruh kalangan masyarakat semakin meluas, bukan saja pada orang dewasa, tetapi juga terjadi di kalangan anak sekolah, bahkan pada anak usia dini. Dalam tindak kekerasan, khususnya perilaku bullying pada anak usia dini, sasaran maupun pelaku bullying yang kedua pihak merupakan anak yang berusia dini, sungguhnya hanyalah merupakan dampak dari pengaruh lingkungan dan kekeliruan orang tua dalam menerapkan pola pendidikan bagi anak, baik di dalam keluarga, di sekolah, maupun di masyarakat. Untuk mengatasi tindak bullying, diperlukan langkah-langkah penanganan, namun untuk mencegah perilaku tersebut dibutuhkan langkah-langkah preventif yang bersifat mencegah. Mencegah lebih efektif dari pada menangani.
\end{abstract}

Kata kunci: Bullying, Penanganan Bullying, Pencegahan Bullying

\section{PREVENT MORE EFFECTIVELY THAN ON THE HANDLE (THE CASE OF BULLYING AT EARLY CHILDHOOD)}

\begin{abstract}
The phenomenon of violence that is happening in the rest of society is increasingly widespread, not only in adults but also occurs among school children, even in early childhood. In the acts of violence, particularly the behavior of bullying on early childhood, targets or perpetrators of bullying which both parties was the son of an early old, behold, is but an impact from environmental influences and the confusion of parents in applying the pattern of education for children, both within the family, at school and in the community. To address acts of bullying, handling steps required, but to prevent such behaviour required preventive measures are preventing. Prevent more effectively than on the handle.
\end{abstract}

Keywords: Bullying, Bullying Prevention, Bullying Handling

\section{PENDAHULUAN}

Mengacu pada UU Nomor 23 Tahun 2002, anak adalah seseorang yang belum berusia 18 tahun. Dalam kajian ini, batasan anak khusus untuk analisis pendidikan yaitu sampai usia 18 tahun atau kurang dari 19 tahun. Hal ini disesuaikan dengan kelompok usia sekolah anak, yaitu anak SD dengan rentang usia 7 sampai 12 tahun, anak SMP berusia 13 sampai 15 tahun, dan anak berusia SMA 15-18 tahun.

Anak sebagai peserta didik di sekolah, seperti halnya manusia pada umumnya, yang memiliki ciri khas dasar yaitu kemampuan untuk berkembang, menalar abstrak, berbahasa dan berkomunikasi, melakukan introspeksi dan memecahkan masalah. Anak merupakan makhluk individu sekaligus merupakan makhluk sosial. Sebagai makhluk individu, anak adalah makhluk yang memiliki kemampuan diri, kemauan, pikiran dan perasaan yang berbeda antara satu dengan yang lainnya. Anak juga merupakan makhluk sosial yang memiliki kemampuan dalam hal berkomunikasi sosial untuk mengekspresikan diri, bertukar ide dan mengorganisasikan diri. 
Setiap anak dalam peranannya sebagai bagian dari struktur sosial pasti akan mengembangkan norma-norma sosial, spritual serta membentuk dasar-dasar kehidupan masyarakat. Dengan demikian maka setiap anak akan terlibat dalam kerja sama dan persaingan dalam pergaulannya sehari-hari. Setiap anak memiliki keinginan untuk memahami dan menerima orang lain, bahkan sebaliknya setiap anak memiliki keinginan untuk dipahami dan diterima olah orang lain. Dalam proses pemahaman akan keinginan orang lain, setiap anak akan mengalami proses yang berbedabeda, hal ini dipengaruhi oleh sikap dan kepribadian anak, serta latar belakang keluarganya. Contoh perilaku yang ditampilkan anak dalam kehidupan sosialnya adalah perilaku anti sosial dan perilaku pro sosial.

Anak yang cenderung mengalami hambatan dalam proses sosial, biasanya akan menampilkan perilaku anti sosial. Gangguan kepribadian berupa perilaku anti sosial, bukan saja perilaku yang ditampilkan oleh anak berupasikap malu dan lebih suka sendiri. Namun lebih dari itu, perilaku ini lebih kepada sikap dan tindakan yang tidak memperhitungkan presensi orang lain di sekililingnya. Wikipedia (2017) mengemukakan bahwa perilaku anti sosial (dengan atau tanpa tanda penghubung) adalah perilaku yang kurang pertimbangan untuk orang lain dan yang dapat menyebabkan kerusakan pada masyarakat, baik sengaja atau melalui kelalaian, karena bertentangan dengan perilaku pro-sosial, perilaku yang membantu atau bermanfaat bagi masyarakat.

\section{PERILAKU BULLYING DALAM KEHIDUPAN ANAK}

Perilaku menyimpang dalam bentuk kekerasan fisik dan psikispada akhir-akhir ini semakin mengemuka. Telah banyak terdapat korbanyang berasal dari seluruh kalanganmasyarakat baik dari kalangan dewasa maupun di kalangan anak-anak bahkan di kalangan anak usia dini. Fenomena tersebut dapat dijumpai dalam kehidupan sehari-hari, dari pemberitaan di media secara luas baik media cetak, media elektronik dan melalui internet.

Mengacu pada Undang-Undang Nomor 23 tahun 2002, perlindungan anak adalah segala kegiatan untuk menjamin dan melindungi anak dan hak-haknya agar hidup, tumbuh, berkembang, dan berpartisipasi, secara optimal sesuai dengan harkat dan martabat kemanusiaan, serta mendapat perlindungan dari kekerasan dan diskriminasi.

Sejak tahun 2006 Badan Pusat Statistik (BPS) mencatat, kasus kekerasan pada anak mencapai Rp 25 juta, dengan berbagai macam bentuk, dari yang ringan sampai yang berat. Lalu, data BPS tahun 2009 menunjukkan kepolisian mencatat, dari seluruh laporan kasus kekerasan, 30 persen di antaranya dilakukan oleh anak-anak, dan dari 30 persen kekerasan yang dilakukan anak-anak, 48 persen terjadi di lingkungan sekolah dengan motif dan kadar yang bervariasi (Sholihat, 2017). Hingga pertengahan tahun 2017, Kementerian Sosial (Kemensos) telah menerima ratusan laporan terkait intimidasi alias bullying. Laporan tersebut diterima melalui pengaduan langsung dan telepon pengaduan (cnnindonesia, 2017).

Direktur Rehabilitasi Sosial Anak Kementerian Sosial mengungkapkanbahwa tahun 2017 pihaknya semakin banyak menerima laporan bullying dibandingkan tahun lalu. Total laporan yang diterima sampai Juni 2017 sebanyak 976 kasus. Sekitar 400 kasus mengenai kekerasan seksual dan sekitar 117 kasus mengenai bullying. Kemudian kasus anak dengan hukum sekitar 214 kasus dan anak terlantar sekitar 165 kasus(cnnindonesia, 2017). Selanjutnya dijelaskan bahwa walau mengalami kenaikan, namun hal itu tidak mengartikan bahwa tingkat kekerasan tumbuh.Data tersebut justru memperlihatkan bahwa tingkat kesadaran masyarakat untuk melaporkan kasus kekerasan semakin tinggi.

Komisi Perlindungan Anak Indonesia (KPAI) menerima 26 ribu kasus anak dalam kurun 2011 hingga September 2017. Laporan tertinggi yang diterima KPAI adalah anak yang berhadapan dengan hukum."Anak berhadapan dengan hukum sebanyak 34 persen salah satu contohnya kasus kekerasan Thamrin City. Selanjutnya permasalahan keluarga dan pengasuhan 19 persen," kata Komisioner KPAI Retno Listyarti dalam diskusi 'Stop Bullying di Sekolah' di DPP Partai Solidaritas Indonesia (PSI), Jl KH Wahid Hasyim, Jakarta Pusat, Rabu tgl 4 Oktober 2017 (KPAI, 2017).Laporan Komisi Nasional Perlindungan Anak (Komnas PA) menyatakan bahwa 80 persen anak yang mengalami tindak kekerasan adalah anak di bawah umur 15 tahun. Bentuk perlakuan salah terhadap anak-anak Indonesia ini meliputi fisik, emosional, sosial dan seksual. 


\section{FENOMENA BULLYING PADA ANAK USIA DINI}

Dalam Bahasa Indonesia, secara harfiah kata bully berarti penggertak, orang yangmengganggu orang lemah. Istilah bullying dalam Bahasa Indonesia,bisa menggunakan "Menyakat" (berasal dari kata sakat) dan pelakunya (bully) disebut penyakat (Poerwadarminta, 1983). Bullying adalah suatu perilaku sadar yang dimaksudkan untuk menyakiti dan menciptakan teror bagi orang lain yang lebih lemah. Komisi Nasional Perlindungan Anak (2017) mendefinisikan bullying sebagai suatu bentuk kekerasan fisik dan psikologis berjangka panjang yang dilakukan seseorang atau kelompok terhadap seseorang yang tidak mampu mempertahankan diri dalam situasi dimana ada hasrat untuk melukai atau menakuti orang atau membuat orang tertekan, trauma/ depresi dan tidak berdaya.

Perilaku bullying tidak hanya terjadi pada anak usia sekolah jenjang SD, SMP dan SMA. Namun fenomena perilaku tindak bullying ini juga dapat terjadi pada anak yang tergolong berusia lebih muda yaitu anak usia dini. Anak yang berada pada lembaga pendidikan Taman Kanak-kanak berada pada rentang usia antara 4 sampai 6 tahun. Lembaga Taman Kanak-kanak adalah lembaga yang termasuk dalam program PAUD (Pendidikan Anak Usia Dini). Usia dini yang dimaksud adalah anak yang berada pada rentang usia 0 sampai 6 tahun, atau biasa disebut dengan anak pra sekolah.

School "bullying" adalah perilaku agresif yang dilakukan berulang-ulang oleh seorang/sekelompok siswa yang memiliki kekuasaan terhadap siswa/siswi lain yang lebih lemah dengan tujuan menyakiti orang tersebut.Bentuk perilaku bullying tersebut dapat berupa: (1) kekerasan fisik (mendorong, menendang, memukul, menampar), (2) secara verbal (Misalnya panggilan yang bersifat mengejek atau celaan), (3) secara mental (mengancam, intimidasi, pemerasan, pemalakan), (4) secara sosial, misalnya menghasut dan mengucilkan (Ahmad, 2015).

Komisioner KPAI Bidang Pendidikan, Retno Listiyarti (2017) mengakui bahwa hingga kini kekerasan di dunia pendidikan kian memprihatinkan.Berdasarkan data Ikhtisar Eksekutif Startegi Nasional Penghapusan Kekerasan Terhadap Anak 2016-2020 yang dirilis oleh Kementerian Pemberdayaan
Perempuan dan Perlindungan Anak (KemenPPPA), menunjukan sebanyak 7 dari 10 siswa pernah mengalami kekerasan di sekolah. Sebanyak $45 \%$ siswa laki-laki dan $22 \%$ siswa perempuan menyebutkan, guru atau petugas sebagai pelaku kekerasan di sekolah.Sedangkan 40\% siswa usia 13-15 tahun dilaporkan pernah mengalami kekerasan fisik oleh teman sebaya, dan $75 \%$ siswa mengaku pernah melakukan kekerasan di sekolah. Lebih parah, sebanyak $50 \%$ anak dilaporkan mengalami perundungan atau bullying di sekolah.

Professor Dan Olweus (1993) yang dikutip oleh Tisna Rudi (2010: 4) mengemukakan bahwa perilaku bullying mengandung tiga unsur mendasar perilaku bullying, yaitu: (1) bersifat menyerang (agresif) dan negatif, (2) dilakukan secara berulang kali, (3) adanya ketidakseimbangan kekuatan antara pihak yang terlibat. Olweus kemudian mengidentifikasikan dua subtipe bullying, yaitu perilaku secara langsung (direct bullying), misalnya penyerangan secara fisik dan perilaku secaratidak langsung (indirect bullying), misalnya pengucilan secara sosial. Underwood, Galen, dan Paquette (2001) dalam Tisna Rudi (2010) mengusulkan istilah "Social Aggression" untukperilaku menyakiti secara tidak langsung.

Pada anak usia dini, mayoritas kehidupan anak adalah bermain, baik bermain sendiri maupun dengan teman-temannya. Pada saat kegiatan bermain bersama, maka muncul suatu interaksi sosial, dengan demikian potensi untuk terjadi tindakan kekerasan, pemaksaan kehendak dan perbedaan pendapat dapat saja terjadi. Ketika terjadi permasalahan dalam interaksi antar anak, ada anak yang dapat menyelesaikannya dengan baik, namun ada pula yang tidak. Anak yang tidak dapat menyelesaikan masalah dengan baik pun terbagi dua, yaitu mereka yang menggunakan kekerasan dan mereka yang pasrah.

Bila selama ini kita hanya melihat bullying terjadi pada jenjang SD ke atas (SMP dan seterusnya), beberapa penelitian telah membuktikan bahwa bullying dapat terjadi pada anak TK. Contoh perilaku bullying antara lain mengejek, menyebarkan rumor, menghasut, mengucilkan, menakut-nakuti (intimidasi), mengancam, menindas, memalak, atau menyerang secara fisik (mendorong, menampar, atau memukul).

Banyak pihak menganggap bahwa pada usia dini sikap dan perilaku anak selalu dapat dikontrol sehingga berpendapat bahwa perilaku 
bullying tersebut merupakan hal sepele atau bahkan "normal" dalam kehidupan sehari-hari. Namun demikian, perilaku bullying merupakan sesuatu gangguan yang dialami oleh anak yang berupa "learned behaviors". Bullying merupakan perilaku tidak "normal", tidak sehat dan secara sosial tidak bisa diterima. Karena manusia tidak terlahir sebagai penggertak dan pengganggu yang lemah. Dengan demikian jika perilaku mengganggu dilakukan secara berulang kali pada akhirnya dapat menimbulkan dampak serius dan fatal di kemudian hari

\section{ANAK SEBAGAI KORBAN BULLYING}

Anak usia dini yang mengalami perilaku bullying biasanya akan menunjukkan beberapa perubahan dalam keadaan fisik dan psikisnya. Anak sebagai korban biasanya akan merasakan berbagai emosi negatif, seperti marah, dendam, tertekan, takut, malu, sedih, tidak nyaman, terancam, tetapi tidak berdaya menghadapinya. Dalam jangka panjang, kondisi ini dapat mengembangkan perasaan rendah diri dan tidak berharga. Bahkan, tak jarang ada yang ingin keluar dan pindah ke sekolah lain. Dampak psikologis yang lebih berat adalah kemungkinan untuk timbulnya masalah pada korban, seperti rasa cemas berlebihan, selalu merasa takut, dan depresi.

Bullying juga berpengaruh pada kegiatan bermain anak. Bullying mengakibatkan anak menjadi lebih nyaman untuk bermain sendiri dari pada bermain dengan teman-temannya. Bullying memang merupakan tindakan agresif, namun tidak semua tindak agresif digolongkan sebagai bullying, kecuali jika tindakan agresif itu dilakukan berulang-ulang oleh pelaku yang sama terhadap korban yang sama, dan perilaku tersebut memang diniatkan untuk menyakiti korban.

Sholihat (2017) mengungkapkan ciri-ciri yang harus diperhatikan pada anak yang dapat diwaspadai sebagai korban bullying adalah di antaranya: (1) enggan untuk pergi sekolah, (2) sering sakit secara tiba-tiba, (3) mengalami penurunan nilai, (4) barang yang dimiliki hilang atau rusak, (5) mimpi buruk atau bahkan sulit untuk terlelap, (6) rasa amarah dan benci semakin mudah meluap dan meningkat, (7) sulit untuk berteman dengan teman baru, dan (8) memiliki tanda fisik, seperti memar atau luka.

Orang tua yang mendapatkan anak usia dini dengan keadaan fisik dan psikis yang menjurus pada kecurigaan bahwa anak kemungkinan adalah korban bullying hendaknya menjadi lebih waspada. Guru di sekolah hendaknya juga memiliki kepekaan dan kepedulian yang tinggi pada peserta didiknya, khususnya jika ditinjau dari peranan guru sebagai orang tua kedua bagi anak di sekoah. Dengan demikian semua pihak dapat saling bersinergi untuk menyelamakan anak dari dampak buruk bullying di dalam kehidupannya sehari-hari dan mencegah dampak jangka panjang yang akan dialami oleh anak.

\section{ANAK SEBAGAI PELAKU BULLYING}

Pelaku Bullying pada anak biasanya merupakan pihak yang dekat dengan anak. Pelaku dapat dibagi menjadi dua golongan, yaitu pelaku utama dan pelaku pengikut. Pelaku utama adalah pihak yang merasa lebih berkuasa dan berinisiatif melakukan tindak kekerasan baik secara fisik maupun psikologis terhadap korban. Sedangkan pelaku pengikut yaitu pihak yang ikut melakukan bullying berdasarkan solidaritas kelompok atau rasa setia kawan, konformitas, tuntutan kelompok, atau untuk mendapatkan penerimaan atau pengakuan kelompok. Namun, dalam hal ini tindak bullying juga biasanya melibatkan pihak lain selain diri korban, pelaku, dan pelaku pengikut. Orang atau pihak lain yang menyaksikan terjadinya peristiwa bullying adalah saksi. Saksi ini biasanya hanya bisa diam membiarkan kejadian berlangsung, tidak melakukan apapun untuk menolong korban, tetapi juga bahkan seringkali mendukung perlakuan bullying. Saksi cenderung tidak mau ikut campur disebabkan karena takut menjadi korban berikutnya, merasa korban pantas dibully, tidak mau menambah masalah atau tidak mau tahu (Yosep, 2014)

Perilaku bullying pada anak, khususnya pada anak usia dini, di mana pelakunya juga adalah anak usia dini dapat saja merupakan teman sepermainan anak, maupun anak lain yang bukan teman sepermainan anak. Bullying sebagai suatu tindakan yang mengganggu orang lain, bisa secara fisik, verbal, atau emosional. Bullying sering kali terlihat sebagai perilaku pemaksaan atau usaha menyakiti secara fisik ataupun psikologis terhadap seseorang atau kelompok yang lebih "lemah" oleh seseorang atau sekelompok orang yang mempersepsikan dirinya lebih "kuat".

Secara psikologis, anak yang agresif kurang memiliki kontrol diri, memiliki ketrampilan sosial yang rendah; memiliki empati yang tidak berkembang, dan mengalami salah suai. Anak meyakini bahwa agresi merupakan 
cara pemecahan masalah yang tepat dan efektif. Biasanya anak dengan ciri-ciri tersebut adalah anak yang berasal dari lingkungan keluarga dengan model pengasuhan yang tidak kondusif.

Lebih jauh, anak pelaku bullying cenderung mengalami kelekatan (attachment) yang tidak aman dengan pengasuh terdekatnya, dapat pula terjadi pada anak dengan orang tua yang menerapkan disiplin yang terlalu keras ataupun terlalu longgar. Hal lain yang menjadi penyebab adalah adanya masalah psikologis pada orang tua, konflik suami-istri, depresi, bersikap antisosial, dan melakukan tindak kekerasan pada anggota keluarganya.

Perilaku bullying pada anak, khususnya jika anak adalah pelaku sebenarnya bisa dicegah. Pihak sekolah dan orangtua hendaknya memiliki pemahaman yang menyeluruh mengenai anak. Kunci utama dari antisipasi masalah disiplin dan bullying adalah hubungan yang baik dengan anak. Hubungan yang baik akan membuat anak terbuka dan percaya bahwa setiap masalah yang dihadapinya akan bisa diatasi dan bahwa orangtua dan guru akan selalu siap membantunya. Dari sinilah anak kemudian belajar untuk menyelesaikan masalah dengan cara yang tepat.

\section{PENANGANAN BULLYING PADA ANAK USIA DINI}

Morrison (2016: 892) respon pendidik terhadap seorang anak yang diduga mengalami aniaya dan pengabaian adalah sebagai berikut: (1) tetap tenang;anak akan menahan informasi, menariknya atau berhenti bicara jika merasakan reaksi kuat dari pendidik, (2) percayailah anak; anak jarang mengarang cerita tentang aniaya, (3) dengarkan tanpa menghakimi; kebanyakan anak kenal penganiayanya dan mengalami konflik perasaan dalam dirinya, (4) beritahu anak bahwa anda senang dia mau bercerita, (5) lakukan apa yang dapat anda lakukan untuk memastikan anak tidak lagi menghadapi aniaya lebih jauh setelah bercerita kepada anda.

Bila orangtua mendeteksi bahwa anaknya justru menjadi pelaku, jangan tutupi kesalahan anak, karena korbannya di luar sana terancam mengalami gangguan emosi berkepanjangan, seperti rasa takut yang berlebihan dan menjadi rendah diri. Orangtua dapat membacakan ceritacerita mengenai anak-anak yang baik dan mau meminta maaf bila berbuat salah, kemudian mengajak anak berdiskusi mengenai cara-cara yang baik dan sopan dalam menyelesaikan masalah dengan teman.

Penanganan pada anak yang menjadi pelaku bullying menurut Shalihat (2017), adalah sebagai berikut: (1) segera ajak anak bicara mengenai apa yang ia lakukan. Jelaskan bahwa tindakannya merugikan diri dan orang lain. Upayakan bantuan dari tenaga ahlinya agar masalah tertangani dengan baik dan selesai dengan tuntas, (2) cari penyebab anak melakukan hal tersebut. Penyebab menjadi penentu penanganan. Anak yang menjadi pelaku karena rasa rendah diri tentu akan ditangani secara berbeda dengan pelaku yang disebabkan oleh dendam karena pernah menjadi korban.Demikian juga bila pelaku disebabkan oleh agresifitasnya yang berbeda, dan (3) Posisikan diri untuk menolong anak dan bukan menghakimi anak (Sholihat, 2017).

Penanganan paling ideal adalah apabila ada kebijakan dan tindakan terintegrasi yang melibatkan seluruh komponen mulai dari guru, murid, kepala sekolah, sampai orangtua, yang bertujuan untuk menghentikan perilaku bullying dan menjamin rasa aman bagi korban.

$$
\text { Langkah selanjutnya adalah }
$$

menyampaikan guru di sekolah. Hal ini ditujukan agar guru lebih memperhatikan situasi dan kondisi anak, sehingga guru dapat segera tanggap bila tindakan agresif kembali terulang di kelas. Pada umumnya pembelajaran mengenai moral dan bagaimana berinteraksi sosial yang baik merupakan fokus utama dalam pendidikan di Taman Kanak-kanak, oleh karena itu guruguru di TK sudah pasti mempunyai variasi cara yang kreatif dan sesuai bagi usia anak untuk dapat membantu mereka memahami apakah perilaku anak didik sudah baik atau masih perlu dilakukan pembinaan.

\section{STRATEGI MENCEGAH BULLYING}

Undang-Undang Dasar 1945 beserta Amandemennya Pasal 28b ayat 2: "Setiap anak berhak atas kelangsungan hidup, tumbuh dan berkembang serta berhak atas perlindungan dari kekerasan dan diskriminasi". Berdasarkan hal tersebut, dapat dipastikan bahwa seluruh anak Indonesia memiliki hak untuk dilindungi dari tindak kekerasan, termasuk dilindungi pertumbuhan dan perkembangannya sehingga tidak melakukan tindak kekerasan kepada orang lain dan kepada dirinya sendiri.

Seorang anak harus dijaga tumbuh kembangnya, dan harus dimaknai sebagai 
sebuah bentuk pemenuhan kesejahteraan rohani anak sehingga tercipta tata kehidupan dan penghidupan anak yang dapat menjamin pertumbuhan dan perkembanganya dengan wajar secara jasmani dan rohani.Bagaimanapun tindakan agresif (baik bagi pelaku maupun bagi korban) bukanlah hal yang dapat dibenarkan. Anak usia dini, khususnya TK yang berusia 4 sampai 6 tahun seharusnya sudah mampu menahan perasaan dan mengendalikan reaksi. Pencegahan munculnya perilaku agresif pun harus dilakukan sejak dini, karena sudah banyak penelitian yang membuktikan bahwa perilaku anak usia dini dapat memprediksi kemampuan penyesuaiannya terhadap lingkungan di masa depan. Anak usia prasekolah yang sudah dapat menunjukkan simpati dengan teman, cenderung akan dapat mempertahankan kemampuannya untuk berempati.Maka sudah jelas bahwa anakanak harus diajak untuk bersikap baik dengan orang lain sejak dini.

Selanjutnya, secara lebih spesifik Undang-Undang Perlindungan Anak Nomor 23 Tahun 2002 pasal 54 menyatakan bahwa: "Anak wajib dilindungi dari tindakan kekerasan yang dilakukan oleh guru, pengelola sekolah atau temannya di dalam sekolah yang bersangkutan, atau lembaga pendidikan lainnya".

Program anti-bullying pada anak di sekolah dapat dilakukan dengan cara menggiatkan pengawasan dan pemberian sanksi secara tepat kepada pelaku, atau melakukan kampanye melalui berbagai cara. Memasukkan materi bullying ke dalam pembelajaran akan berdampak positif bagi pengembangan pribadi para murid.

Langkah mudah mencegah bullying pada anak usia dini dapat dikemukakan sebagai berikut:

1) Orang tua dan orang dewasa lainnya hendaknya membangun komunikasi yang akrab dengan anak, dengan demikian dapat cepat mendeteksi dan mengantisipasi segala sesuatu yang bersifat menyimpang.

2) Membentuk sikap prososial yang kuat pada anak sedini mungkin, sehingga anak mudah beradaptasi dan berkepribadian kuat.

3) Memberikan perhatian dan kasih sayang yang cukup pada anak sehingga mereka akan berperilaku baik jika di luar rumah. Untuk langkah yang ketiga ini lebih diterapkan agar anak tidak menjadi pelaku bullying kepada temannya

\section{PENUTUP}

Tujuan pendidikan bagi anak, khususnya bagi anak usia dini adalah: a) mengembangkan potensi anak secara optimal sesuai dengan tahap perkembangannya, agar memiliki kesiapan memasuki jenjang pendidikan selanjutnya; dan b) membekali anak dengan pengetahuan, keterampilan dan sikap agar memiliki kemampuan untuk kehidupan di masa depan.

Tujuan umum perlindungan bagi anak adalah untuk menjamin pemenuhan hak-hak kelangsungan hidup, tumbuh kembang, perlindungan, dan partisipasi anak. Adapun tujuan khusus yang hendak dicapai adalah: a) menjamin perlindungan khusus bagi anak dari berbagai tindak perlakuan tidak patut, termasuk tindak kekerasan, penelantaran, dan eksploitasi; b) menjamin perlindungan hukum baik dalam bentuk pembelaan dan pendampingan bagi anak yang berhadapan dengan hukum agar hakhaknya tetap terpenuhi, dan terlindungi dari tindak diskriminatif; dan c) mengakui dan menjamin hak anak dari komunitas minoritas untuk menikmati budaya, menggunakan bahasa, dan melaksanakan ajaran agamanya.

Pada dasarnya seluruh anak membutuhkan perlindungan, namun anak usia dini adalah salah satu golongan anak yang perlu membutuhkan perlindungan khusus. Perlindungan khusus yang dimaksud adalah perlindungan dan pemberian lingkungan yang aman bagi pertumbuhan dan perkembangannya, termasuk perlindungan dari tindak kekerasan fisik dan psikis. Dalam kasus-kasus tertentu, anak usia dini adalah korban sekaligus pelaku dari tindak kekerasan, khususnya tindak bullying. Namun demikian yang perlu diingat adalah bahwa anak usia dini yang menjadi pelaku bullying sesungguhnya adalah korban perlakuan atau peristiwa dari fenomena lain sebagai sebuah rentetan peristiwa penyebab perlakuannya tersebut. Lingkungan dan orang tua menjadi faktor utama dalam pembentukan karakter anti bullying pada anak.

\section{DAFTAR PUSTAKA}

Ahmad, Ghulam. 2015. Pencegahan Terjadinya Perilaku Kekerasan (Bullying) melalui Program Anti Bullying di Sekolah. Panduan bagi Guru dan Tenaga Kesehatan. [online].
Tersedia: 
http://www.disdikcianjur.org/post/re ad/155/pencegahan-terjadinyaperilaku-kekerasan- bullyingmelalui-program-anti-bullying-disekolah.html, [16 Desember 2017].

CnnIndonesia. 2017. Semakin Banyak yang Melaporkan Kasus Bullying. [Online]. Tersedia: https://www.cnnindonesia.com/gayahidup/20170722163858-277229641/semakin- banyak-yangmelaporkan-kasus-bullying/, $[2$ Desember 2017].

Morrison, George S. 2016. Pendidikan Anak Usia Dini Saat Ini. Edisi 13. Terjemahan. Yogyakarta: Pustaka Pelajar

Poerwadarminta, W.J.S. 1983. Kamus Umum Bahasa Indonesia. PN Balai Pustaka.

Kompasiana, 2012. Bullying di Usia Dini. [online]. Tersedia: https://www.kompasiana.com/.../bull ying-di-usiadini_551294b7a333110f5dba7d39,

[19 Desember 2017]

Listiyarti, Retno. 2017. Pengeroyokan murid SD. [Online]. Tersedia: http://www.kpai.go.id/berita/tanggap an-kpai-soal-video-pengeroyokanmurid-sd-di-sumatera-selatan-readmore-at-httpskumparan comkumparannewstanggapan-kpaisoal-video-pengeroyokan-murid-sddi-sumatera selatanzkkdqr7eellxyfzu/, [ 19 Desember 2017]

Rudi, Tisna. 2010. Informasi Perihal Bullying. Indonesian Anti Bullying. E-book.

Sholihat, Neni. 2017. Cara Mengatasi Bullying. [Online]. Tersedia: https://nsholihat.wordpress.com/tag/ cara- mengatasi-bullying/, [ 13 November 2017].
Undang-Undang Dasar 1945 beserta Amandemennya

Undang-Undang Nomor 23 Tahun 2002 tentang Perlindungan Anak

Yosep, Santoso. 2014. Bullying Di Sekolah, Cara Pencegahan dan Penanganannya. [Online]. Tersedia: http://www.smaksantoyosephdenpas ar.sch.id/news/2014/175/1/0/Bullyin g-Di-Sekolah-- Cara Pencegahan-dan Penanganannya.html, [13 November 2017] 